\title{
Whipple's disease in a female with impaired cell-mediated immunity unresponsive to co-trimoxazole and levamisole therapy
}

\author{
M. R. HAENEY \\ M.B., M.Sc., M.R.C.P.(U.K.) \\ I. N. Ross \\ M.B., M.R.C.P.(U.K.) \\ Metabolic Unit, East Birmingham Hospital, Birmingham B9 5ST
}

\begin{abstract}
Summary
A case of Whipple's disease in a female is described. Malabsorption of iron, vitamin $B_{12}$, folic acid and fat was present. These abnormalities reverted to normal after introduction of co-trimoxazole therapy. The patient's humoral immune system was normal, in contrast to impairment of cell-mediated immunity, which has not improved in spite of co-trimoxazole treatment for 2 years, and a therapeutic trial of levamisole.

These findings are further evidence that there may be a primary immune deficiency in patients with Whipple's disease.
\end{abstract}

\section{Introduction}

Whipple's disease is a rare, systemic illness which usually affects middle-aged males. It is characterized morphologically by periodic acid-Schiff staining macrophages in virtually every organ system but maximally involving the lamina propria of the proximal small intestine and the mesenteric lymph nodes. In a recent review, 238 patients were reported as having Whipple's disease, of whom only thirtythree were female (Miksche et al., 1974).

This report records the occurrence of Whipple's disease in a female with evidence of impaired cellmediated immunity before treatment. Although clinical remission was induced with co-trimoxazole, evidence of impaired cellular immunity persisted. A therapeutic trial of levamisole for four months produced no significant improvement in her immune status. This lack of response supports the contention that primary impairment of cellular immunity is directly involved in the pathogenesis of Whipple's disease.

\section{Immunological methods}

Quantitative serum immunoglobulins and immunochemical serum complement levels were measured by single radial immunodiffusion. $\mathrm{T}$ lymphocytes were estimated by their ability to form

Correspondence: Dr M. R. Haeney, Regional Immunology Laboratory, East Birmingham Hospital, Bordesley Green East, Birmingham B9 5ST.
E rosettes with sheep red blood cells by the method of Jondal, Holm and Wigzell (1972). B-lymphocytes, i.e. cells bearing surface membrane immunoglobulin (SmIg), were quantified by immunofluorescence with anti-human $\mathrm{Fab}$ and anti-human $\mu$ chain antisera according to the method of Papamichail, Brown and Holborow (1971). SmIg and E rosettes are standard tests of $B$ and $T$ cell enumeration respectively. The whole blood culture method was used to quantitate lymphocyte transformation responses to mitogens and antigens (Paty and Hughes, 1972).

\section{Case report}

A 54-year-old female presented in November 1970 with an 18-month history of joint pains responding symptomatically to phenylbutazone. This was a seronegative, non-erosive, arthropathy affecting the elbows, shoulders, neck and proximal interphalangeal joints of both hands, In March 1973, she developed abdominal pain, episodic diarrhoea and night sweats. Examination revealed anaemia, bilateral axillary lymphadenopathy and intermittent pyrexia up to $39^{\circ} \mathrm{C}$. She was found to have a microcytic anaemia with a haemoglobin of $7.9 \mathrm{~g} / \mathrm{dl}$ but a barium meal, barium enema and sigmoidoscopy were normal. Mantoux and Kveim tests were negative. She had steatorrhoea of 53 $\mathrm{mmol} /$ day (normal range $<17$ ) with positive faecal occult blood and abnormal xylose absorption. A barium follow-though examination showed a nonspecific malabsorption pattern. Peroral jejunal biopsy was unsuccessful. A provisional diagnosis of coeliac disease was made and she was started on a trial of gluten-free diet.

In April 1974, she was transferred to the Metabolic Unit of the East Birmingham Hospital. She was cachexic, anaemic, with palmar erythema and bilateral axillary lymphadenopathy. There was abdominal distension, but rectal and sigmoidoscopic examinations were normal.

\section{Investigations \\ Haematology}

Haemoglobin, $11.7 \mathrm{~g} / \mathrm{dl}$; film normochromic 
and normocytic; white blood cell count, $5.1 \times 10^{9} / 1$; direct lymphocyte count, $0.78 \times 10^{9} / 1$; ESR $50 \mathrm{~mm}$ fall/hr; serum iron, $2.86 \mu \mathrm{mol} / \mathrm{l}$; iron binding capacity, $40 \mu \mathrm{mol} / \mathrm{l}$; serum folate $2 \cdot 2 \mu \mathrm{g} / 1$; serum vitamin $\mathrm{B}_{12}, 418 \mathrm{ng} / \mathrm{l}$; direct Coombs' test, negative. Bone marrow examination showed micro-normoblastic erythropoiesis with evidence of defective haemoglobinization, in the presence of a marked increase in iron stores.

\section{Biochemistry}

Urea and electrolytes normal; serum calcium, 1.98 $\mathrm{mmol} / \mathrm{l}$; serum phosphate, $1.23 \mathrm{mmol} / \mathrm{l}$; serum magnesium, $0.74 \mathrm{mmol} / \mathrm{l}$; alkaline phosphatase, 35 i.u. $/ 1$; total serum proteins, $55 \mathrm{~g} / 1$; serum albumin, $27 \mathrm{~g} / \mathrm{l}$; serum orosomucoids, $2.0 \mathrm{~g} / \mathrm{l}$ (normal range $0 \cdot 30-1 \cdot 20 \mathrm{~g} / \mathrm{l})$.

\section{Immunology}

Quantitative immunoglobulin estimations, lymphocyte transformation responses, and $T$ and $B$ cell estimations are shown in Tables 1 and 2. Antinuclear factor and Rose-Waaler test were negative. No serum cryoglobulins were detected.

\section{Intestinal function}

Faecal fat and nitrogen excretions averaged 123 and $214 \mathrm{mmol} /$ day respectively during a 10-day balance period (normal range $<17.4$ and $71-142$ $\mathrm{mmol} /$ day respectively). Iron absorption: following $100 \mathrm{mg}$ of ferrous sulphate orally, the serum iron rose by only $3 \mu \mathrm{mol} / 1$. Xylose absorption: $4 \%$ of the $5 \mathrm{~g}$ dose was excreted in the urine in the first 2 hours (normal range $>15 \%$ ) and $16 \%$ in the total 5 -hour period (normal range $35 \pm 14 \%$ ); the 1 -hr blood xylose level was $0.62 \mathrm{mmol} / 1$ (normal range 0.65 1.33). A double isotope Schilling test showed malabsorption of vitamin $\mathbf{B}_{12}$ with and without intrinsic factor. Bromsulphthalein retention and urinary indican were normal. No pathogens were cultured from the stools and no ova, cysts or parasites were seen on microscopy.

Barium follow-through examination showed coarse mucosal folds in the duodenum and jejunum.

Culture of the jejunal aspirate grew Escherichia coli, Clostridium welchii and Proteus mirabilis but no ova, cysts or parasites were seen. Levels of trypsin, lipase and cholic acid in the fluid were normal.

She was initially considered to have a primary gastrointestinal lymphoma with a contaminated small bowel syndrome. The bacterial overgrowth was treated with co-trimoxazole for a period of 2 weeks and it was noted that her faecal fat excretion fell to a mean of $35.2 \mathrm{mmol} / 24 \mathrm{hr}$. A diagnostic laparotomy showed enlarged mesenteric lymph nodes and dilatation of the jejunum and ileum. The spleen measured only $10 \mathrm{~cm}$ along its longi- tudinal axis. A full thickness jejunal biopsy was taken $10 \mathrm{~cm}$ distal to the duodeno-jejunal junction and a mesenteric node excised.

\section{Histology}

The dissecting microscope appearance was of stout, swollen, finger-like or tongue-like villi. Unde light microscopy (Fig. 1), the appearances were of Whipple's disease, with marked distension of the villi by accumulation in the lamina propria of manyo large histiocytes with abundant cytoplasm fille 65 with PAS-positive granules. Immunofluoresence of the jejunal biopsy showed IgG deposition along్ the epithelial basement membrane and in the submucosa with increased numbers of $\operatorname{IgA}$ and IgNS plasma cells around the base of the crypts. The्छ histology of a mesenteric lymph node was also that of Whipple's disease, histiocytes containing PAS N positive granules and lipid-filled foam cells being present in abundance. Culture of the lymph nodes failed to grow any pathogenic organisms, including Yersinia enterocolitica.

Following the diagnosis of Whipple's disease, she was restarted on co-trimoxazole in standard dosage plus folic acid supplements, with improvement in hes clinical condition (Fig. 2).

\section{Progress}

Regular reassessment has shown clinical biochemical improvement (Fig. 2). After 2 months oह therapy, vitamin $\mathbf{B}_{12}$ absorption was normalō Reassessment at 1 year revealed elevated seruno transaminases and $\mathrm{HB}_{\mathrm{s}} \mathrm{Ag}$ was found to be positive in serum, saliva, jejunal juice, urine and faeces $\overrightarrow{0}$ Percutaneous liver biopsy was consistent with $\mathbf{B}$ residual stage of viral hepatitis and scattered cells were positive for $\mathrm{HB}_{\mathrm{s}} \mathrm{Ag}$ both on orcein staining and्क्त. using $\mathrm{a} \mathbf{H B}_{\mathrm{s}} \mathrm{Ag}$ antiserum in indirect immuno fluorescence. Retrospective analysis of stored serum?. samples showed $\mathrm{HB}_{\mathrm{s}} \mathrm{Ag}$ to have been absent at the time of diagnosis but present 3 months later.

She has continued on co-trimoxazole and waş well when reviewed 18 months after diagnosis. $A^{3}$ repeat jejunal biopsy was normal but cutaneous anergy to various antigens was still present and lymphocyte transformation responses to mitogens? antigens studied in vitro were mostly still impaired compared with controls (Table 1). The effect of the immunopotentiating agent levamisole was ther investigated. The patient was given levamisole, $150 \mathrm{~W}$ $\mathrm{mg}$ twice weekly for 2 months followed by $150 \mathrm{mg}$ daily for 2 months. There was no fluctuation in hero clinical state. Parameters of humoral and cell mediated immunity were reassessed at the end of each 2-month period of levamisole therapy (Tables? 1 and 2). The impairment of cellular immunity persisted despite this treatment. 


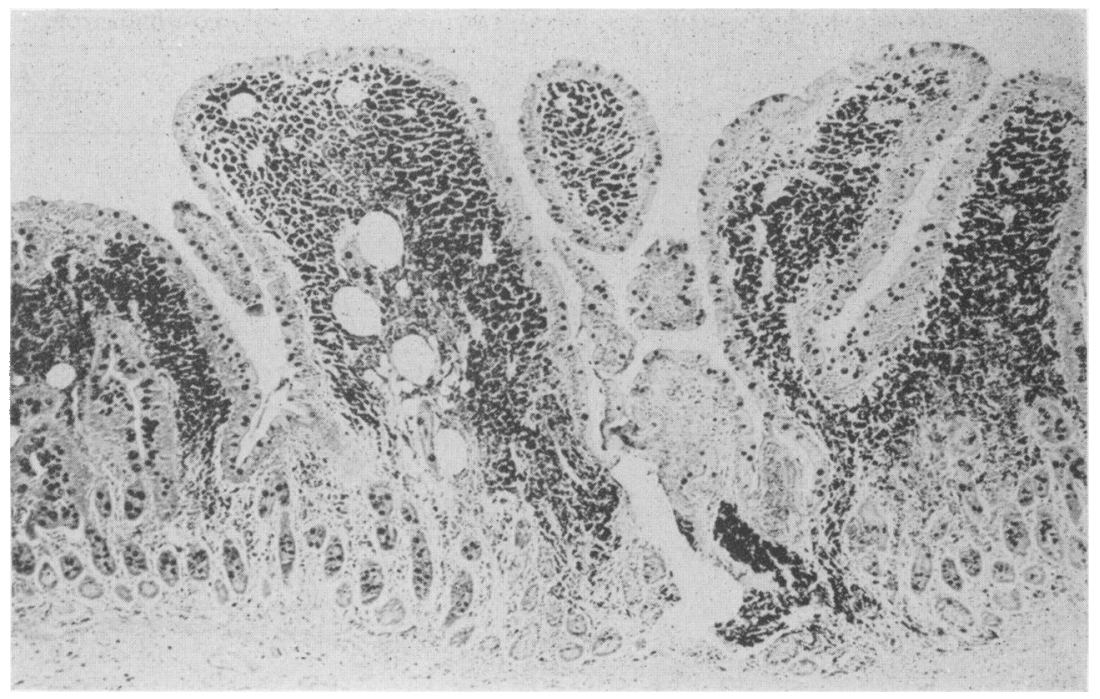

FIG. 1. Jejunal biopsy showing villi distended by characteristic PAS-staining macrophages in the lamina propria. $(\times 77)$

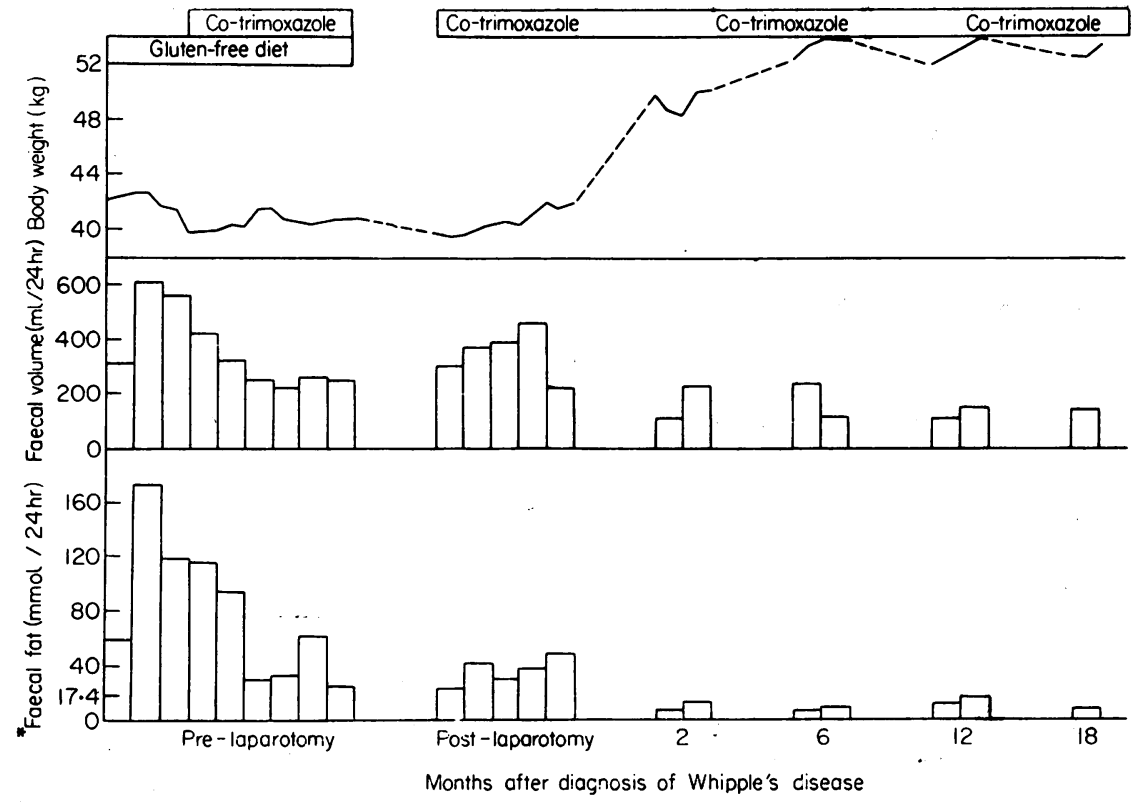

Fig. 2. Clinical response to co-trimoxazole. ${ }^{*}$ Faecal fat results taken over a 5-day mean. 
TABLE 1. Response of cell-mediated immune function to co-trimoxazole and levamisole therapy

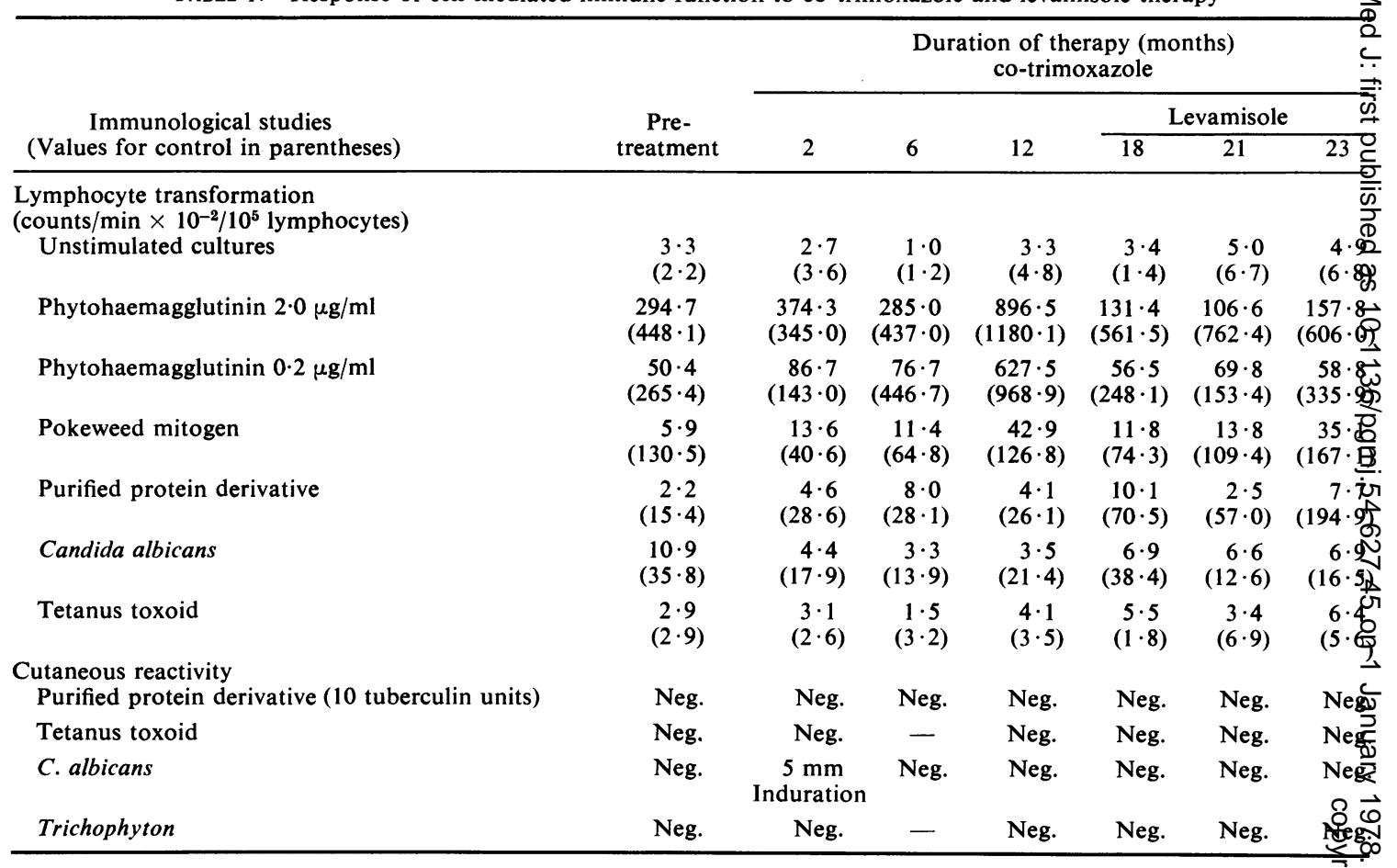

TABLE 2. Response of serum immunoglobulins, serum complement and lymphocyte sub-populations to co-trimoxazole $\underset{\vec{a}}{\overrightarrow{7}}$. levamisole therapy

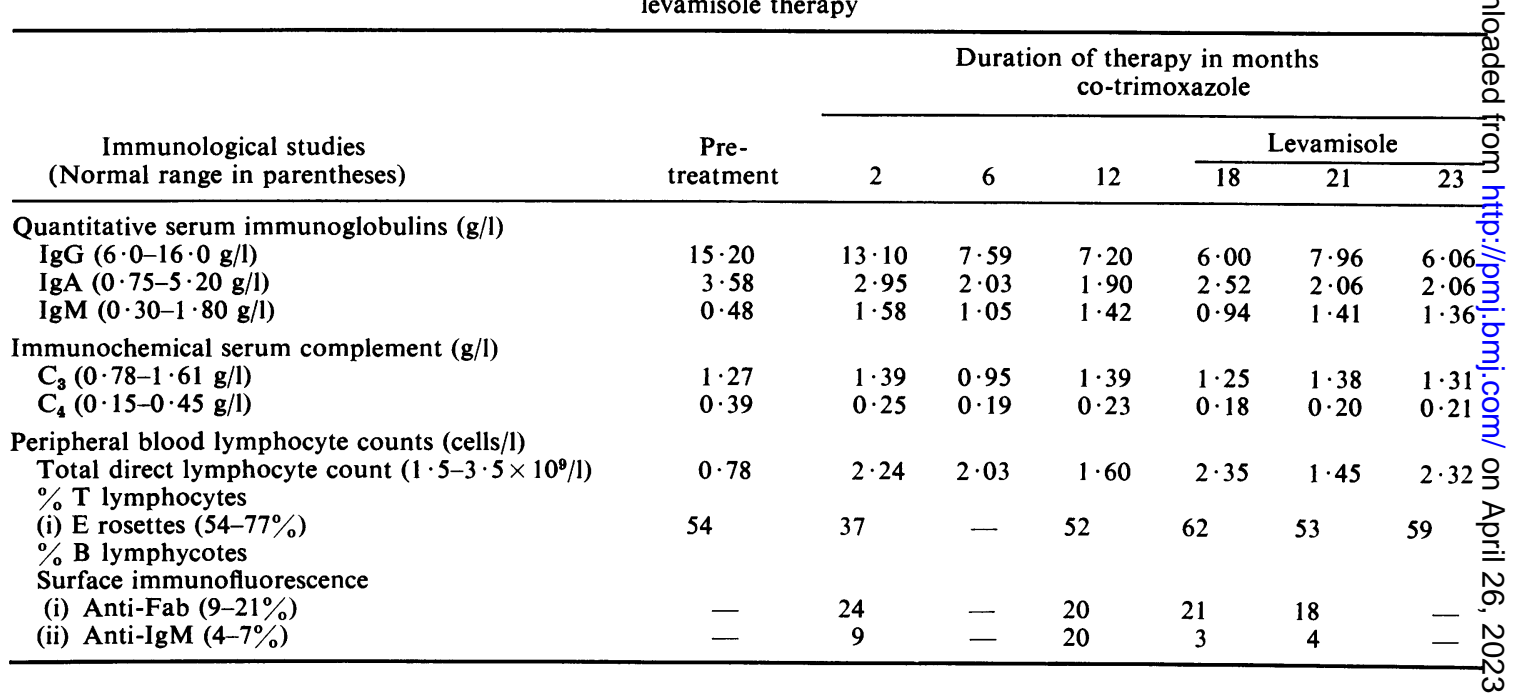

\section{Discussion}

The arthropathy, recurrent pyrexia, peripheral lymphadenopathy and malabsorption present in this case are well documented features of Whipple's disease (Whipple, 1907; Maizel, Ruffin and Dobbins, 1970). The pathological findings in the jejunal biopsy and mesenteric lymph node fulfil the accepted criteria for its diagnosis (Maizel et al., 1970). In the patient described, there was evidence of a functional? defect in both the proximal small intestine (abnormato iron and xylose absorption) and distal small in testine (abnormal double-isotope Schilling test) 
Only two other cases of significant malabsorption of vitamin $\mathrm{B}_{12}$ have been documented (Gross et al., 1959; Paul, 1967), involvement of the distal small bowel being usually regarded as less severe than proximal disease (Maizel et al., 1970).

Immunological studies of Whipple's disease have emphasized the cellular findings (Martin et al., 1972). The significant lymphopenia initially present in the patient described affected both $\mathrm{T}$ and $\mathrm{B}$ lymphocyte sub-populations. This lymphopenia and the return to normal levels on treatment led Pastor and Geerken (1973) to suggest that, in untreated cases, there may be lymphatic obstruction with loss of lymph into the gastrointestinal tract. Untreated patients have generally shown depressed or absent responses to skin testing with a variety of antigens. In the case described pre-treatment cutaneous anergy was present and persisted despite otherwise successful therapy (Table 1). This is in agreement with the findings of Martin et al. (1972) but contrasts with other reports of partial or complete conversion of skin reactivity (Groll et al., 1972; Pastor and Geerken, 1973). In vitro lymphocyte transformation responses to various mitogens and antigens were impaired both before and after treatment (Table 1), suggesting the defect was primary. This is supported by the fact that eleven of a total of thirteen patients studied have shown depressed responsiveness to phytohaemagglutinin in the post-treatment phase (Maxwell et fal., 1968; Watson, Maxwell and Ferguson, 1969; Martin et al., 1972; Groll et al., 1972; Pastor and Geerken, 1973).

Where assessment of splenic size in Whipple's disease has been possible, the spleen was usually normal, although splenomegaly has been documented in at least six patients in the literature (Maizel et al., 1970). The small spleen found at laparotomy in the present patient may be aetiologically related to the cellular deficit demonstrated, but no objective assessment of splenic function was made. The contined presence of $\mathrm{HB}_{\mathbf{s}} \mathrm{Ag}$ despite clinical recovery and levamisole therapy could be taken as further evidence of defective cell-mediated immunity; patients with impaired $\mathrm{T}$ cell systems are known to be susceptible to viral diseases (Soothill, 1975).

With respect to humoral immunity, no clear-cut pattern of pre-treatment immunoglobulin levels has yet emerged. Groll et al (1972) demonstrated elevation of all immunoglobulin classes in their patients, but others have reported slight decreases in IgG with normal IgA and IgM levels (Case Records, 1971 ; Pastor and Geerken, 1973). Hypogammaglobulinaemia has been reported in four patients with Whipple's disease (Sandor and Kozmer, 1967; Martel and Hodges, 1959; Anton, 1961; Cochran et al., 1973) and Berens, Cohen and Schwabe (1969) described a patient with decreased IgM levels. Posttreatment immunoglobulin levels have tended to be normal, with the exception of $\operatorname{IgM}$, which has been variously reported as depressed (Maxwell et al., 1968; Groll et al., 1972) or elevated (Pastor and Geerken, 1973). The present patient had a highnormal pre-treatment IgG level which has fallen to a low-normal level on therapy, while IgA and IgM levels have always been normal (Table 2). Immunofluorescence of the jejunal biopsy showed increased numbers of plasma cells, particularly of $\operatorname{IgA}$ and IgM type, perhaps reflecting an increased mucosal response to local antigenic challenge. The serum complement activity, as reflected by serum $\mathrm{C} 3$ and $\mathrm{C} 4$ levels, has remained within the normal range before and after treatment.

Since Paulley (1952) reported the successful use of antibiotics, a variety of different drugs has been tried and found effective to varying degrees (Miksche et al., 1974). Co-trimoxazole was initially used in the present patient to treat her contaminated small-bowel syndrome, but it also appears to have been effective in the treatment of the Whipple's disease (Fig. 2); Elsborg, Gravgaard and Jacobsen (1975) have also documented a case in whom this drug was used beneficially.

Any hypothesis of the aetiology of Whipple's disease must take into account its rarity, predilection for male Caucasians, predominant involvement of the gastrointestinal tract, and the histological observation of bacilliform bodies in the intestinal lesion. The true role of micro-organisms in this condition is not clearly defined but a cell-wall deficient form of an $\alpha$-haemolytic streptococcus has recently been isolated from prolonged monolayer cultures of a lymph node taken from a patient with Whipple's disease (Clancy et al., 1975). There is also some suggestion that host factors may be of prime importance. Evidence of impaired cell-mediated immunity in individuals with Whipple's disease (Maxwell et al., 1968; Watson et al., 1969; Martin et al., 1972; Groll et al., 1972; Pastor and Geerken, 1973) raises the possibility that a primary immune deficit predisposes to the development of the condition and the findings in the present patient support this suggestion.

Levamisole, an effective anthelmintic, has been shown to have immunopotentiation effects (Leading Article, 1975). In man, it has been reported as restoring delayed hypersensitivity responses in individuals with anergy associated with old age and malignant disease (Tripodi, Parks and Brugmans, 1973; Leading Article 1975). Clinical usefulness for levamisole has been claimed in a range of disorders (Leading Article, 1975) and in vitro, levamisole appears to activate functionally defective $T$ cells (Verhaegen et al., 1975; Biniaminov and Ramot, 
1975). No significant improvement in the present patient's lymphocyte transformation responsiveness or cutaneous anergy was seen after 4 months of levamisole therapy (Table 2). This lack of response again suggests that the cellular defect in this patient was primary. Based on the evidence in the literature and the experience gained from the present case, it seems possible that impaired cell-mediated immunity is directly involved in the pathogenesis of Whipple's disease.

\section{Acknowledgments}

We are grateful to Professor J. Hardwicke for permission to study and report this patient; Dr J. Bayliss of Bedford Hospital for the original referral; Dr R. A. Thompson of the Regional Immunology Laboratory, East Birmingham Hospital, for kindly performing the immunological investigations and to Dr P. Asquith for reviewing the manuscript and for his helpful criticisms.

\section{References}

ANTon, A.T. (1961) Agammaglobulinemia complicating Whipple's disease-Case Report. Ohio State Medical Journal, 57, 650.

Berens, S.C., Cohen, R.A. \& Schwabe, A.D. (1969) Diagnostic problems of a partially treated Whipple's disease. Report of a case of isolated deficiency of IgM. California Medicine, 110, 477.

BINIAMINOV, M. \& RAMOT, B. (1975) In vitro restoration by levamisole of thymus-derived lymphocyte function in Hodgkin's disease. Lancet, i, 464.

CASE Records of the Massachusetts General Hospital (1971) Weekly clinico-pathological exercises: case 35 . New England Journal of Medicine, 285, 567.

Clancy, R.L., Tomkins, W.A.F., Muckle, T.J., RichardSON, H. \& RAWLS, W.E. (1975) Isolation and characterisation of an aetiological agent in Whipple's disease. British Medical Journal, 3, 568.

Cochran, M., Cook, M.G., Gallagher, J.C. \& Peacock, M. (1973) Hypogammaglobulinaemia with Whipple's disease. Postgraduate Medical Journal, 49, 355.

Elsborg, L., GravgaArd, E. \& Jacobsen, N.O. (1975) Treatment of Whipple's disease with sulphamethoxazoletrimethoprin. Acat medica scandinavica, 198, 141.

Groll, A., VAlberG, L.S., SimON, J.B., Eidinger, D., WILSON, B. \& FORSDYKE, D.R. (1972) Immunological deficit in Whipple's disease. Gastroenterology, 63, 943.

Gross, J.B., Wollaeger, E.E., SAYer, W.G., Huizenga, K.A., Dahlin, D.C. \& Power, M.H. (1959) Whipple's disease; report of four cases, including two in brothers with observations on pathology, physiology, diagnosis and treatment. Gastroenterology, 36, 65 .

HENDRIX, J.P., BlaCK-SHAFFER, B., Withers, R.W. \& HANDLER, P. (1950) Whipple's intestinal lipodystrophy: report of 4 cases. Archives of Internal Medicine, 85, 91.

JoNDAl, M., Holm, G. \& Wigzell, H. (1972) Surface markers of human $T$ and B lymphocytes. I. A large population of lymphocytes forming non-immune rosettes with sheep red blood cells. Journal of Experimenta Medicine, 136, 207.

Leading Article (1975) Levamisole. Lancet, i, 151

Maizel, H., Ruffin, J.M. \& Dobbins III, W.O. (1970): Whipple's disease: a review of 19 patients from on hospital and a review of the literature since 1950. Medicine. Baltimore, 49, 175.

MARTEL, W. \& Hodges, F.J. (1959). The small intestine i Whipple's disease. American Journal of Roentgenology, $8 \frac{1}{\frac{1}{2}}$ 623.

Martin, F.F., Vilseck, J., Dobbins, W.O., III. Buckley C.E. \& TYOR, M.P. (1972) Immunological alterations i\$p patients with treated Whipple's disease. Gastroenterology 63, 6.

MaXWell, J.D., Ferguson, A., MCKay, A.N., ImRIE, R. $\overrightarrow{\dot{c}}$ \& WATSON, W.C. (1968). Lymphocytes in Whipple disease. Lancet, $\mathrm{i}, 887$.

MiksChe, L.W., BLÜmCKe, S., FritsChe, D., Kücheman K., SChÜller, H.W. \& Grözinger, K.H. (1974) Whipple? disease: Etiopathogenesis, treatment, diagnosis an clinical course. Case report and review of the world literis ture. Acta hepato-gastroenterologica, 21, 307.

Papamichail, M., Brown, J.C. \& Holborow, E.J. (1971.) Immunoglobulins on the surface of human lymphocytes Lancet, ii, 850.

Pastor, B.M. \& Geerken, R.G. (1973) Whipple's disease presenting as pleuropericarditis. American Journal of Medicine, 55, 827.

PATY, D.W. \& Hughes, D. (1972) Lymphocyte transformå tion using whale blood culture: an analysis of response Journal of Immunological Methods, 2, 99.

PAUL, F.A. (1967) Whipple's disease: a review of literatore and case report. West Virginia Medical Journal, 63, 49 .

PaUlley, J.W. (1952) A case of Whipple's disease (intestịP lipodystrophy), Gastroenterology, 22, 128.

SANDOR, T. \& KOZMER, J. (1957) In: Magyar belorvosi arthp vum, 98. Quoted in Postgraduate Medical Journal, (1973) $49,355$.

SooTHILl, J.F. (1975) Immunity deficiency states. Irf్ Clinical Aspects of Immunology, 3rd Edn, pp. 649-68 Ed. Gell, P. G. H., Coombs, R. R. A. and Lachmann P.J. Blackwell Scientific Publications, Oxford.

Tripodi, D., Parks, L. C. \& Brugmans, J. (1973) Druga induced restoration of cutaneous delayed hypersensitivity in anergic patients with cancer. New England Journal Medicine, 289, 354.

Verhaegen, H., DeCock, W., Decree, J., Verbruggen, Fơ Verhaegen-DeclercQ, M. \& Brugmans, J. (1975) In vitzô. restoration by levamisole of thymus-derived lymphocyio function in Hodgkin's disease. Lancet, i, 978.

Watson, W.C., Maxwell, J.D. \& Ferguson, A. (196\%) Lymphocytes in Whipple's disease. Proceedings of th? Royal Society of Medicine, 62, 986.

WhipPLE, G.H. (1907) A hitherto undescribed disease characterised anatomically by deposits of fat and fatty acids in the intestine and mesenteric lymphatic tissue Bulletin of the Johns Hopkins Hospital, 18, 382.

YARDLEY, J.H. \& HENDRIX, T.R. (1961) Combined electroñv and light microscopy in Whipple's disease-demonstration of 'bacillary bodies' in the intestine. Bulletin of the Johring Hopkins Hospital, 109, 80. 